\title{
Attributes, Vestments, Context and Inscription in the Identification of Nubian Paintings Proposing the 'Multi-Layer' Image Recognition Method
}

\author{
MAGDALENA ŁAPTAŚ
}

\begin{abstract}
The aim of this paper is to present a method that enables identification of Nubian paintings whose tituli have not been preserved or are incomplete. This method is reminiscent of the laborious piecing together of mosaics from scattered and incomplete tesserae. The attributes, vestments or contexts are such tesserae, which taken into consideration together enable the composing of a mosaic, piece by piece. Some interpretations of the paintings were made during excavations, without time for deeper analysis. Identifications created in this way have become so merged with the images, and then repeated frequently, that it was very difficult to change them and introduce a new perspective on already widely accepted opinions. In this article, I have focused on a few select examples that show how one can identify individual paintings, but also how one can fall into the trap of too easy comparisons and attributions. A scholar studying Nubian art has to be cautious as its iconography is sometimes so original that it cannot be easily compared to Byzantine or any other cultural patterns.
\end{abstract}

Keywords: attribute, vestment, context, iconography, identification, method, Nubian painting, Byzantine art

Magdalena Łaptaś, Art History Institute, Cardinal Wyszyński University in Warsaw, Warsaw; magda.laptas@gmail.com; (1) 0000-0001-6548-8236

Scholars studying Coptic and Nubian iconography often face the problem of the proper identification of wall-paintings. This results from the fact that many paintings have been preserved in a fragmentary state. There are often large fragments of characters and descriptive inscriptions missing. At times, inscriptions are preserved fragmentarily, which allows for a more detailed interpretation.

The aim of my article is to present a method that enables an approximate (and at the same time rather cautious) identification of paintings whose tituli have not been preserved or are incomplete. This method is reminiscent of the laborious assembling of mosaics from scattered and incomplete tesserae. The elements mentioned in the title of this paper 
are like single tesserae, which taken into account independently do not always allow for a final identification. ${ }^{1}$

Attributes greatly contribute to recognising characters, but may have such a general meaning that they should be assigned to a wider group of saints. Let us take into consideration such attributes as books. These objects can be held by Christ, ${ }^{2}$ the apostles, bishops ${ }^{3}$ or other figures counted among the broadly understood group of people engaged in intellectual work. In turn, the vestment is often an element that allows one to determine what function the person performed: whether he was a ruler or a clergyman. ${ }^{4}$ The attributes, in combination with the vestment, enable a narrowing down of the identification of the figures, e.g. a book in combination with a suitable garment make it possible to determine whether a character is a bishop.

However, it is not always possible, without an appropriate inscription, to determine whether the bishop was alive while his image was being painted, although in this case another attribute is helpful - a halo around his head. The physiognomic type is another element that enables identification of a character if it has been preserved in a complete and not fragmentary state, e.g. when the face is not lacking. Sometimes, however, the figures are shown in such a schematic way that the type of physiognomy cannot be a decisive clue in determining the identification. ${ }^{5}$

Context is another element that aids in the process of identifying paintings. This includes the place where the paintings were located within the building, since sacral spaces were subordinated to a specific liturgical and iconographic program. In addition, the role that some characters played in the overall scene can be classified as the context in which they functioned. It is occasionally possible to connect the image with the text behind it, which enables the identification of singular characters.

The last of the elements mentioned in the title are inscriptions, which should be a factor determining the recognition of given figures or whole scenes, especially when they have been preserved in full or when one can be sure that a particular inscription refers specifically to a given painting and not another one. Let us investigate the above initial assumptions on some chosen examples.

${ }^{1}$ Although this method refers to the previously used ones in the history of art, e.g. Erwin Panofsky (1939), its innovation comes from the fact that it shows the practical side of the work on the identification of Christian paintings discovered during excavations in the Sudan, especially the ones which are severely damaged. More on the new research methods of history of art in: Bryl et al. (Eds) 2009.

${ }^{2}$ Iwaszkiewicz-Wronikowska 2003: 135.

${ }^{3}$ Martens-Czarnecka 1974: 309-334.

${ }^{4}$ Woźniak 2014; Innemée 1992.

${ }^{5}$ For example, in room 29 of the North-West Annex of the Monastery on Kom H in Old Dongola, the apostles are shown in such a schematic way that they all look much the same. Cf. Martens-Czarnecka 2001: 268, Pls XLIV-XLV; 2011: 201, 206, Figs 101-103, cat. no. 68, Figs MMC_068_01-15. 
1. An Archangel. Faras

Cathedral, nave, third north pillar, east side; photo in situ (Phot. M. Niepokólczycki; courtesy of IKŚiO PAN).

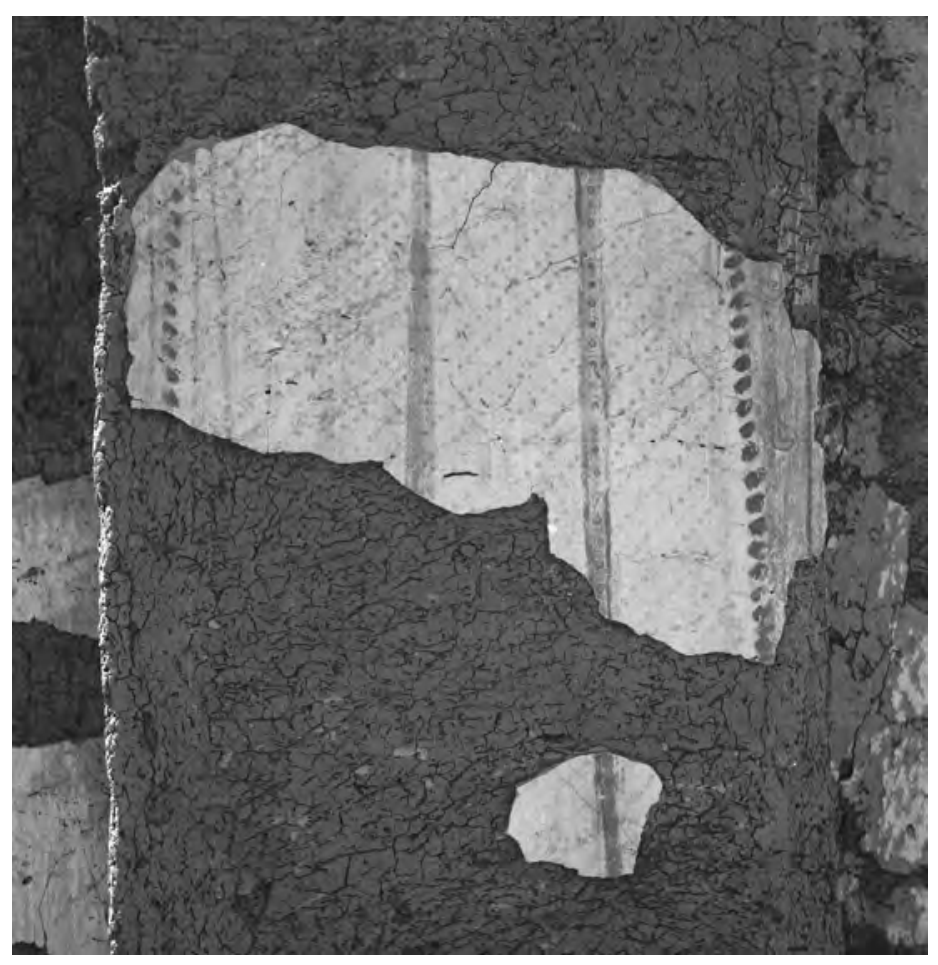

\section{THE ATTRIBUTES}

A painting from the Faras Cathedral, dated to the late tenth/early eleventh century can be presented as the first example. ${ }^{6}$ The mural was not removed from the wall as it had been severely damaged (Fig. 1). At the moment of its discovery, only the middle part of the figure was preserved (without the hands). It was possible to state that the figure's attire consisted of a tunic with two clavi. On the figure's sides, there were two fragments of wings, adorned with single peacock feathers. Until recently, this painting was identified as the Archangel Michael on the basis of the type of wings on which the individual peacock feathers were observable. Wings are thought to be the characteristic attribute of angels and archangels. ${ }^{7}$ However, in the Bible, archangels and angels are described as wingless creatures (and they were presented as such on the oldest Christian monuments). ${ }^{8}$ Wings were added to the images of archangels by the end of the fifth century, under the influence of pre-Christian iconography and the writings of the Church Fathers. ${ }^{9}$ It seems that Nikes

${ }^{6}$ Jakobielski et al. 2017: 228, cat. no. 62.

7 Peers 2001: 23.

8 Jastrzębowska 2011: 153.

${ }^{9}$ Tertullian e.g. wrote: Every spirit is winged; so it is with angels, so it is with demons. Thus in a moment they are everywhere; all the world is to them one spot; what is being done, and where, it is as easy for them to 
and Victories were the direct prototypes for winged archangels and angels; however, many other ancient gods and demons were presented with wings. ${ }^{10}$ Early Nubian images of the archangels, dated to the seventh-eighth centuries, present archangels already with wings, on which feathers are marked in the form of rows of straight lines. ${ }^{11}$ In the eighth century, one can note the appearance of eyes on the archangels' wings, ${ }^{12}$ while in the ninth century peacock feathers were introduced. ${ }^{13}$ Until recently, peacock feathers were considered to be an 'exclusive' element of the Archangel Michael's images. ${ }^{14}$ Nevertheless, the excavations carried out in the Archangel Raphael's Church at the Citadel in Old Dongola by the Polish mission supervised by Włodzimierz Godlewski (in the 2015-2016 season) led to an interesting discovery of paintings depicting the Archangel Rafael. The Archangel was painted in the eastern part of the nave. He was rendered in a standing position, frontally, with lowered wings, adorned with peacock feathers. The well-preserved titulus leaved no doubt as to the identification of this Archangel as Raphael, not Michael. ${ }^{15}$ This discovery verified current opinions and proved that the identification of the murals conducted thus far, especially those without tituli, was very doubtful.

An additional danger faced by scholars results from the too literal comparison of Byzantine and Nubian iconography. An example can be provided by an eight century mural depicting two Archangels, Michael and Gabriel, from Faras Cathedral. ${ }^{16}$ Both images come from the narthex of the building (Fig. 2). The Archangels are shown very similarly, almost like twins. They are clad in long tunics and loroi. Their wings are covered with eye motifs. They are both holding globes in their left hands. However, one of the Archangels is holding a sword in his right hand (Fig. 3), and the second a trumpet (Fig. 4). Had it not been for the well-preserved tituli, scholars would rather have identified the Archangel with the sword as Michael, as he was the commander-in-chief of the heavenly forces. The sword was seen as a weapon with which God punishes sinners, A sword has been sharpened, it has been flashing (Ez 21:8-10). It also symbolised a Judge’s power. In the Last Judgement scenes, Michael was represented bearing a sword and scales (for weighing

know as to tell. Their swiftness passes for divinity, because their real nature is unknown. The Apology 22: 8; see: Tertullian, Apology 1984: 121.

${ }^{10}$ Cf. e.g. Martin 2001: 23; Ostrowski 2003; Krauze 2012: 32-35.

11 Jakobielski et al. 2017: 119-120, cat. no. 4; 146-147, cat. no. 19.

12 Łaptaś 2015: 51.

13 Jakobielski et al. 2017: 173-174, cat. no. 36.

${ }^{14}$ The decoration on the wings (peacock feathers) identifies this figure as the Archangel Michael. He is the only one of the archangels to have this motif depicted on his wings in the late 10th and early 11th century (although later examples are also known). This distinction is evident in the Nativity scene [Cat. No. 70] and in murals of Michael and Gabriel [Cat. Nos 105 and 106], where only Michael's wings feature this decoration. Jakobielski et al. 2017: 228, cat. no. 62.

15 The painting was presented by Włodzimierz Godlewski during a lecture organised by the Institute of Mediterranean and Oriental Cultures, Polish Academy of Sciences in 2016, and by Agnieszka Ryś on the conference 'Poles on the Nile', June 16, 2016.

${ }^{16}$ Jakobielski et al. 2017: 165-166, cat. nos 31-32. 


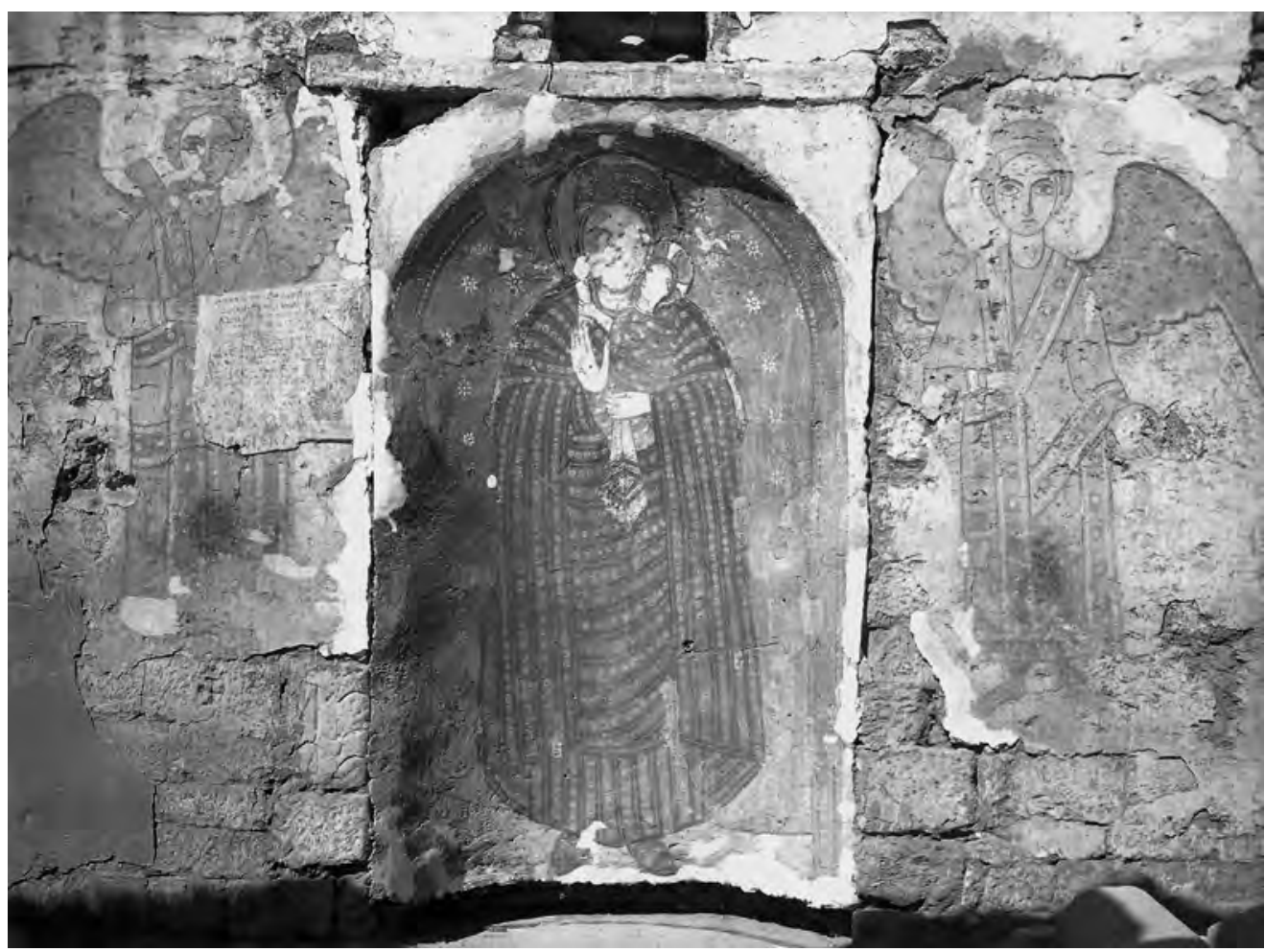

2. The Archangels Michael and Gabriel and the Virgin Eleusa. Faras Cathedral, narthex, western wall; photo in situ (Phot. A. Dziewanowski; courtesy of IKŚiO PAN).

souls). ${ }^{17}$ The famous Byzantine icon (c. 1000-1050), housed in the Treasury of San Marco in Venice, shows Michael as the patron of the Holy Warriors, wielding a sword in his right hand. ${ }^{18}$ Michael was also labelled the archistrategos by the inscriptions accompanying Nubian paintings. Therefore, linking this Archangel with a sword seemed to be the most obvious association. ${ }^{19}$ Yet, in the case of Faras, the titulus labels the Archangel with a sword as Gabriel, whereas the Archangel with a trumpet as Michael.

What was the reason for representing the archistrategos with a trumpet in this specific case? The answer may come from a biblical interpretation. The trumpet was a very powerful instrument. The sound of trumpets led to Jericho's walls falling (Jo 6:4-5). This instrument also performed a major role in the Book of Revelation, in which seven angels were described wielding seven trumpets. When subsequent angels sounded their trumpets

${ }^{17}$ Michael was also depicted with a sword in the following scenes: that of his conversations with Joshua (the Joshua Roll), cf. Weitzmann 1948: 14, Pl. 13, or later, in the Koimesis scenes (when he cut off Jephonias' hands), cf. Pallas 1972: 40-41.

18 Drake Boehm 1984: 171-174, cat. no. 19.

19 As on the sardonyx cameo, housed in the Metropolitan Museum of Art in New York. Cf. Evans (Ed.) 2004: 239, cat. nos 147. 


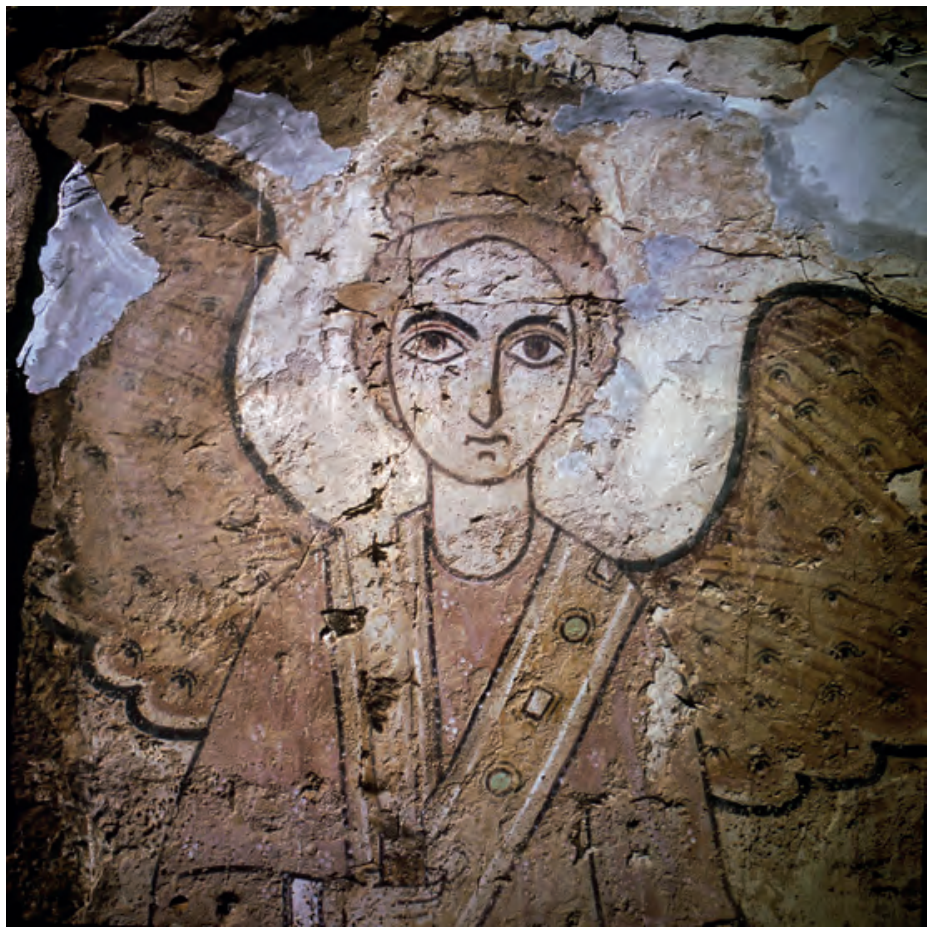

3. Archangel Gabriel, detail of the composition seen on Fig. 2 (Phot. M. Niepokólczycki; courtesy of IKŚiO PAN).

4. Archangel Michael, detail of the composition seen on Fig. 2 (Phot. M. Niepokólczycki; courtesy of IKŚiO PAN).

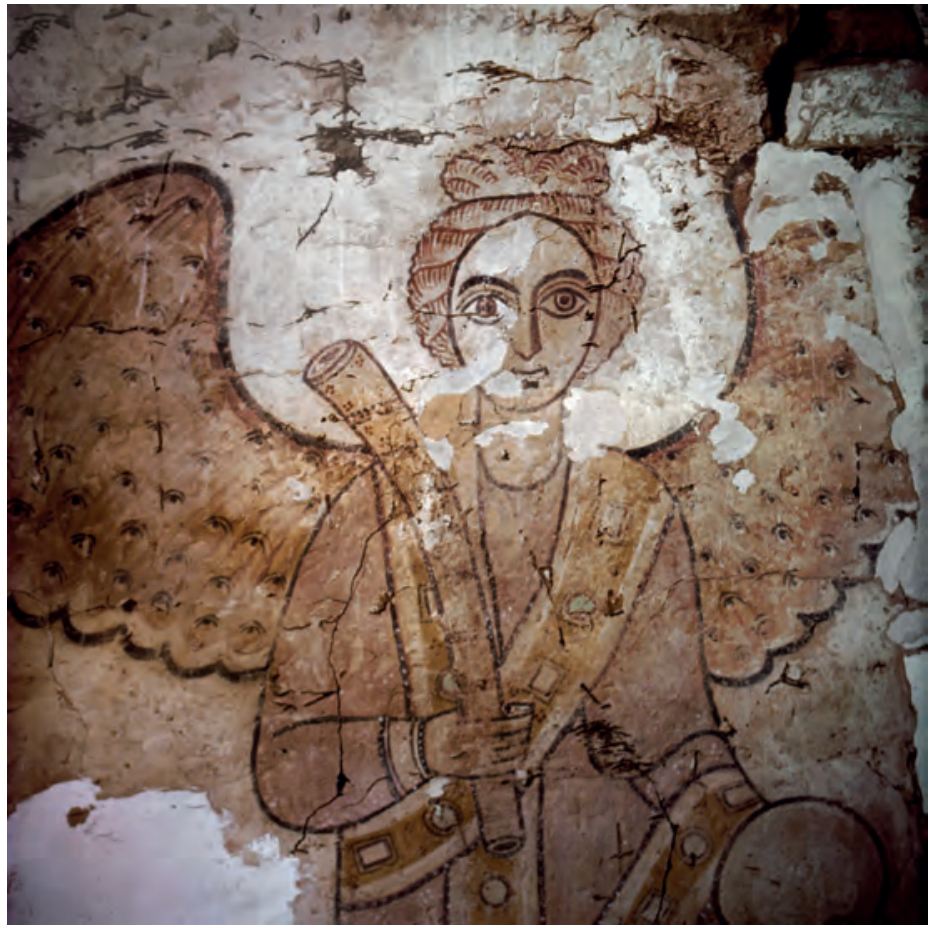


there were further cataclysms in the world, and the sound of the seventh trumpet foretold the Kingdom of the Lord and the Last Judgment (Rv 11:15-18).$^{20}$ Thus, in the case of Faras, Michael was identified with the angel who summoned the Dead to the Last Judgement. In Coptic liturgical texts, such a function was also attributed to Michael. ${ }^{21}$ One should also take into consideration the space in the Faras Cathedral in which the image of Michael was placed. Both Archangels were painted by the western wall of the narthex of the Faras Cathedral, on the wall, where the scenes of the Last Judgment were usually located in Byzantium. Undoubtedly, Archangel Michael's image was in line with this tradition. In this context, one can understand the similar linking of the sword with the image of the Archangel Gabriel. While Michael summoned the Dead to rise, Gabriel separated the Righteous from the Sinners. The fact that both Archangels were placed by the western entrance to the Cathedral additionally made this interpretation more profound by showing that they were guardians, defending holy space from the evil forces wanting to break in.

Finally, it is worth quoting Origen, who in the third century AD wrote that a particular office is assigned to a particular angel: as to Raphael, e.g., the work of curing and healing; to Gabriel, the conduct of wars; to Michael, the duty of attending to the prayers and supplications of mortals (De Principiis I: 8, 1). ${ }^{22}$ As one can see, this theological representative of the School of Alexandria treated Gabriel, not Michael, as the one who conducted wars.

To conclude, scholars wanting to understand Nubian iconography have to avoid making straightforward associations of given attributes with certain characters. Moreover, looking through the Byzantine eye at Nubian iconography can be somewhat tricky, as primarily the tradition flourishing in the Nile Valley should be taken into consideration.

\section{THE VESTMENTS}

One of the elements that can help to identify the character is her/his vestments. At the same time, they do not allow for a precise identification but rather for assigning to a given social group. For example, the sticharion, epitrachelion, phelonion and omophorion enable recognising a character as a bishop. If the bishop has a white face, he can be identified as having been holy or deceased, e.g. St John Chrysostom. ${ }^{23}$ If, however, the skin is darkbrown, it can mean that we are dealing with an image of a Nubian bishop, who was alive while the image was being created. This is confirmed by a formula which appears next to the images, including a wish of many years of life: ПО $\Lambda \Lambda$ A TA ÉTI. ${ }^{24}$

20 Then the seventh angel blew his trumpet, and there were loud voices in heaven, saying: “The kingdom of the world has become, the Kingdom of our Lord and of his Messiah, and he will reign forever and ever" (Rv 11:15), quoted after: Oxford Annotated Bible 2001: 2167.

21 Müller 1959: 11.

22 See translation: Origen, De Pricipiis 1885. See also: Müller 1959: 143.

23 Jakobielski et al. 2017: 194-195, cat. no. 46.

${ }^{24}$ See, e.g. the image of Bishop Marianos, under the protection of the Virgin and Christ in Jakobielski et al. 2017: 308-309. 


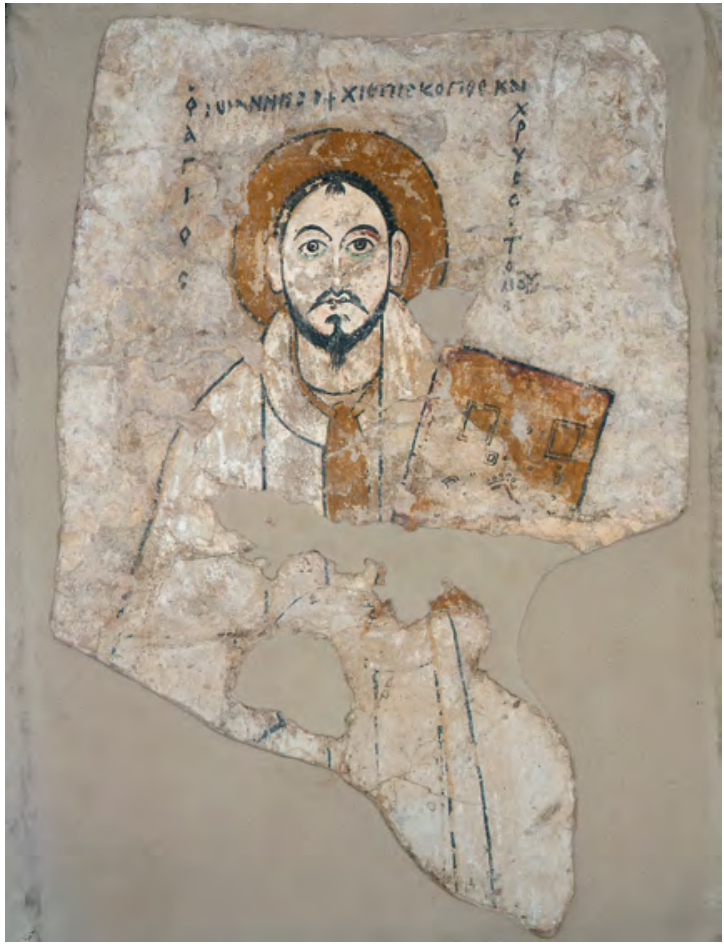

5. St John Chrysostom. Faras Cathedral, south chapel, west wall (Phot. P. Ligier; courtesy of MNW).

Returning, however, to our considerations of the attire, it should be noted that sometimes not all of its elements have been correctly identified. One such example is the already mentioned mural of St John Chrysostom from the Faras Cathedral (Fig. 5). The term 'golden-mouthed' leaves no doubt which saint is represented here. While in this case the inscription precisely defines the presented figure one element raises a lot of doubts as, in my opinion, it has been wrongly interpreted as an object hanging around the saint's neck.

It is an elongated element attached to a rope around the neck and hanging down vertically, at the level of the bishop's chest. Various scholars have interpreted its function differently. Kazimierz Michałowski wrote: He also has a yellow cord round his neck, from which hangs a small yellow object in the form of a mace. It is probably a swarm of bees, one of the Saint's attributes. ${ }^{25}$ Bożena Mierzejewska, in turn, identified this object quite differently: the elongated, yellow object, hanging around the Saint's neck may be a pencil case. ${ }^{26}$ Recently, Stefan Jakobielski has presented a new interpretation: As to the mysterious object worn by St John, it might be a pendant of gold encasing tiny splinters from the Cross of the Crucifixion, which was worn by both men and women around the neck. ${ }^{27}$

25 Michałowski 1974: 143, cat. no. 20.

26 Mierzejewska 2014: 148.

27 Jakobielski et al. 2017: 195. 
6. St John Chrysostom. Hagia Sophia, Constantinople, north tympanum (Phot. P. Grotowski).

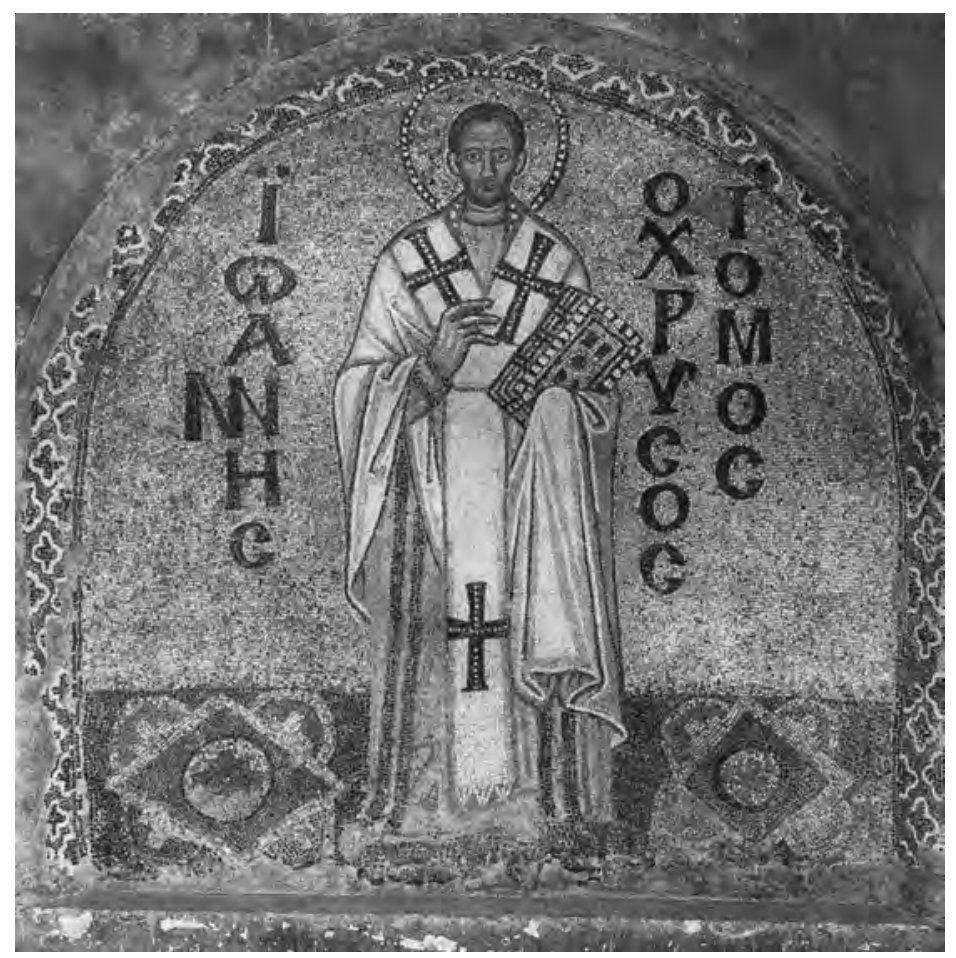

It is puzzling that the above quoted scholars (apart from Jakobielski) have paid any attention to the symbolic significance of the object's colour. This element is yellow, with a delicate, golden shade. The same shade was used to paint the saint's aureole. The aureole was golden (according to the Greek origin of this word), but the Nubians applied a warm shadow of yellow ochre instead of golden leaves. By analogy, the element hanging from St John Chrysostom's neck, painted with the same shade of ochre, was also seen to be golden. St John Chrysostom was referred to as 'the golden-mouthed' due to his eloquent sermons, preached while he was the bishop of Constantinople. ${ }^{28}$

Looking for an analogy to the Nubian image of St John Chrysostom, one can find an example in the very heart of the Byzantine Empire - the Hagia Sophia Church in Constantinople. The northern tympanum of this church contained images of the following bishops, St Ignatius the Younger, St John Chrysostom (Fig. 6) and St Ignatius Theophoros, dated 'to the last two decades of the ninth century'. ${ }^{29}$ Each of the Church Fathers was dressed similarly in a sticharion (tunic) phelonion (chasuble) and an omophorion adorned with crosses. Such vestments were characteristic for bishops and each of these elements had a symbolic meaning. An omophorion resembled a loop loosely draped around the shoulders.

\footnotetext{
${ }^{28}$ Allen, Mayer 2000: 26-33.

${ }^{29}$ Mango, Hawkins 1972: 41, Fig. 17.
} 
The straps of the loop joined on the bishop's chest at one end hanging in front of the figure.

The shape of the omophorion and the way it was draped referred to the image of the lost sheep, which Christ - as the Good Shepherd - had carried in his arms back to the herd. ${ }^{30}$ Omophorion was therefore a symbol of the ecclesiastical authority of bishops, who, like Christ, looked after their flock - that is, the faithful.

It seems, that St John Chrysostom from Faras has just this piece of vestment draped around his shoulders, although it is much shorter than the omophoria known from Byzantine representations. Nevertheless, it must be assumed that the Nubians did not always re-create the patterns known from Byzantium but rather processed them in their own way. The golden shade of St John Chrysostom's omophorion was introduced intentionally to distinguish the golden-mouthed bishop from among the other Church bishops and fathers. Nubiologists from the very beginning adopted the wrong assumption, confusing an element of the attire with an attribute. An additional lack of comparisons with Byzantine examples led to quite risky collations of this element with a 'swarm of bees' or a 'pencil case'. Meanwhile, the saint's actual attribute is simply a codex, held in his left hand, similarly as in images of the bishops in the Hagia Sofia Church.

The colours of the garments are in many cases elements that enable narrowing down the identification of characters, because they have a symbolic meaning. Unfortunately, for many years, this aspect of the colour function has been omitted in Nubian studies in favour of stylistic research. The colour dominants have been treated as a decisive element in dating paintings. This is how the division into: violet, white, yellow-red, red and multi-coloured styles was created. ${ }^{31}$ This division was later elaborated and became even more detailed. ${ }^{32}$ Such a division, apart from being based on an erroneous understanding of the term 'style', did not take into account the degree to which the paintings had been destroyed and the symbolic meaning of the colours. ${ }^{33}$

Additionally, the Nubians who imitated Byzantine patterns used materials easily accessible on their land. As mentioned above, they used golden ochre shades instead of golden leaves and dark-red ochre instead of purple.

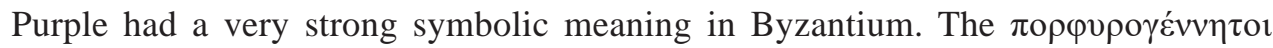
- children born after their fathers had become emperors - formed the elite of the monarchs' families. ${ }^{34}$ Purple appeared as the colour of the Virgin's garments after the Council in Ephesus, held in 431, which declared Mary to be Theotokos - lit. 'God-bearing'. The mosaics on the triumphal arch of Santa Maria Maggiore Church in Rome, ${ }^{35}$ made during Pope Sixtus III's pontificate (432-440), ${ }^{36}$ no longer show Maria as a modest maid but as the

\footnotetext{
30 Patterson Ševcenko 1991: 1526.

31 Michałowski 1974: 29.

32 Jakobielski 1982: 144.

33 Łaptaś 1996: 2-6.

34 McCormick 1991: 1701.

35 Poeschke 2009: 71.

${ }^{36}$ As evidenced by the dedicatory inscription Sixtus Episcopus plebi Dei on the triumphal arch.
} 
7. A Nubian king under protection of the Theotokos with Emmanuel (the second painting layer) and the Theotokos (the first painting layer). Faras Cathedral, apse, the middle part (Phot. P. Ligier; courtesy of MNW).

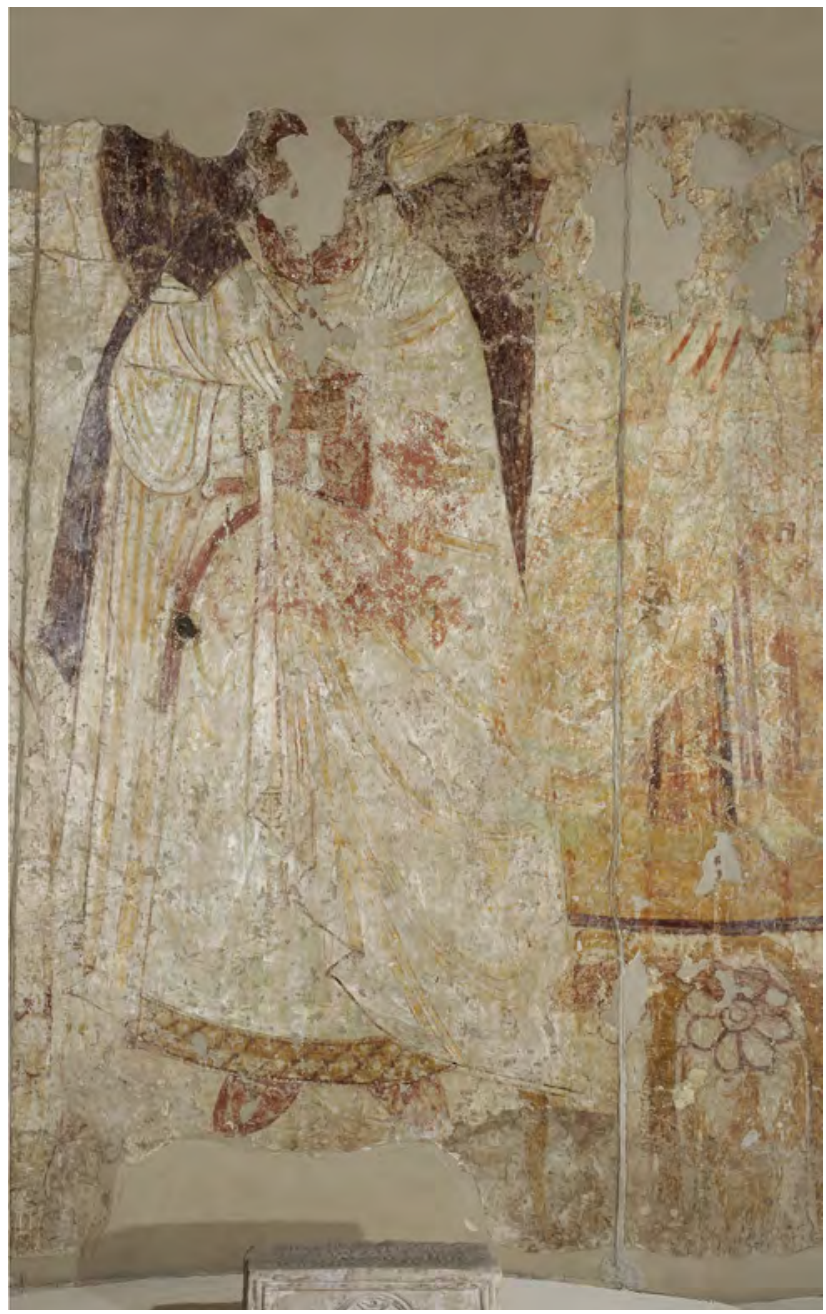

queen of virgins (regina virginorum Ps.-Mt 8:5), wearing golden trabea with a jewelled collar and pearls. ${ }^{37}$

Since the sixth century, images of the Virgin clad in purple were widespread in art. ${ }^{38}$ Paintings from the Faras Cathedral include many images of Maria wearing purple (violet) garments. This colour is seen on images from different periods of the functioning of the Cathedral. The earliest image in the apse of the Cathedral was identified on the basis of this colour. Because the composition in the apse was repainted when the representation of a king was added, Maria's earliest image was covered by his silhouette (Fig. 7).

\footnotetext{
37 Brenk 2010: 72, 77.

38 Petzolt 2017: 442.
} 


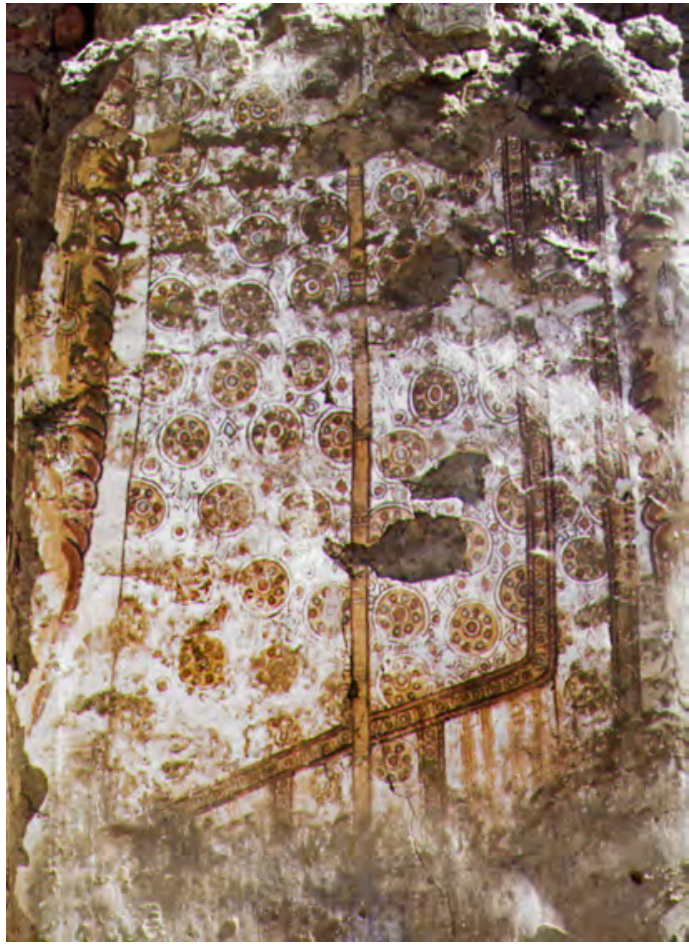

8. The Archangel Michael(?). Faras Cathedral, nave, third north pillar, west side (Phot. M. Niepokólczycki; courtesy of IKŚiO PAN).

However, the purple fragments emerging from underneath the latter make it possible to identify the earliest image.

The apostles were usually represented in white clothes, which had a symbolic meaning, whereas Nubian kings were clad in richly decorated, ornamental garments, emphasising the splendour of royal ceremonies.

The archangels also wore spectacular vestments, embroidered and studded with precious stones. Through such representations, the painters showed the high position of the archangels at the celestial court. It was widely accepted by the scholars that the shape of the clothes as well as the ornaments on them could allow for a precise dating of the paintings. However, this assumption should be revised, taking into consideration that the painted images were sometimes created in isolation from reality. ${ }^{39}$ As an example may serve the painting of the archangel from the Faras Cathedral (Fig. 8) ${ }^{40}$ The archangel is dressed in a loros with a thorakion, richly decorated with rosettes formed from precious stones and pearls. If such a garment were to have actually existed, it would have been impossible to wear by

39 This issue was discussed after the lecture of Magdalena Woźniak entitled 'Nubian Textiles: Craft, Trade, Costume and Identity in the Medieval Kingdom of Makuria', which was held in the Institute of Mediterranean and Oriental Cultures of the Polish Academy of Sciences on $24^{\text {th }}$ October 2017.

40 Jakobielski et al. 2017: 229-230, cat. no. 63. 
an ordinary mortal. However, wearing such a vestment would not have been a problem for an archangel. On the other hand, it is difficult to imagine that a delicate creature with a subtle and ethereal physical form could fly in the sky bearing such a heavy garment. The painter probably wanted to show the archangel's splendour by dressing him in such richly decorated garments. This tendency could also be true of the images of Nubian rulers, who were intentionally represented in extremely richly decorated garments, which could have been the result of an exaggeration of their actual appearance.

Summing up, a garment may be an important factor in the recognition of certain characters but not a decisive one; thus, it should be taken into consideration together with painting's context.

\section{THE CONTEXT}

The context is understood here as the location of the painting within the building, as well as a set of factors or elements related to each other in such a way that they allow for an identification of the entire scene, even though it is incomplete or the physiognomic types have not been preserved. This applies especially to multi-figure scenes or compositions based on written sources. One such example from outside Nubia may be an image considered to be the earliest painting of St Peter the Apostle, dated to the mid-third century, discovered in the Baptistery, in Dura Europos (Fig. 9). ${ }^{41}$ Despite the very schematic image of the Apostle and the silhouette of Christ (only partly preserved), the fact that both figures are walking on water with a boat bearing the other apostles in the background, directs us to a text from the Gospel of Matthew, in which the image of Jesus walking on water is described (Mt 14:28-34). This description, unlike the other ones in the Gospels of Mark (6:45-53) and John (6:15-21), contains the theme of Peter's trial of faith, in which Jesus tested him by telling him to walk on the waves. If it was not for the surroundings and the figures accompanying Peter, it would be difficult to identify him, especially since his head was not surrounded by a halo, which was later a permanent attribute of this saint.

Similar examples can be noted in Nubian paintings. A mural from Faras Cathedral (eight century) has not been preserved in full; however, some figures have been saved fragmentarily, with their faces still visible. One of them can be identified as an angel, due to his wings. As it is one of the earliest paintings from the Cathedral, ${ }^{42}$ the wings are painted in a very schematic way as rows of short strokes (Fig. 10). The angel is holding a sphereglobe in his left hand, an attribute borrowed from imperial iconography, representing God's authority. He is clad in a tunic with two orbiculi at knee height, and a chlamys, fastened on the right arm. To the right and left of the archangel, two standing silhouettes can be observed with their hands raised in the orans gesture. Each of them is wearing a short,

\footnotetext{
${ }^{41}$ Rostovtzeff (Ed.) 1934: 266-270, Pls XLV and LI.

${ }^{42}$ Godlewski 1992: 27, Fig. 3.
} 


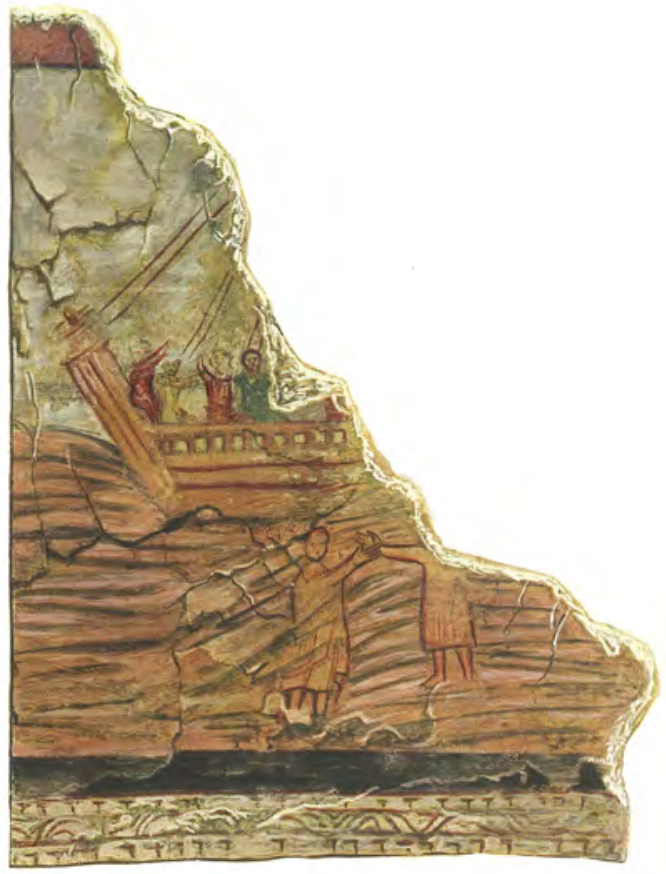

9. Jesus Walking on the Water. Wall-painting in the baptistery of Domus Ecclesiae in Dura Europos (Rostovtzeff (Ed.) 1934: Pl. LI).

10. Three Youths in a Fiery Furnace. Faras Cathedral, inv. no. 234040 MNW (Phot. P. Ligier; courtesy of the MNW).

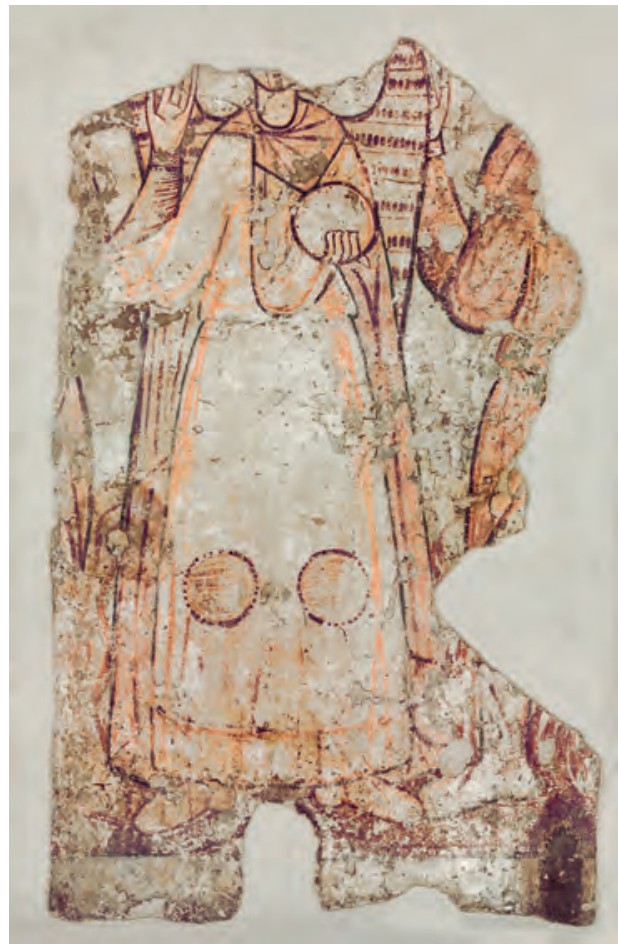


belted tunic, narrow trousers and knee-high boots. Wavy dark-red lines are depicted between the silhouettes and the angel. Both the arrangement of the characters and their praying gesture, in conjunction with the angelic silhouette, enable identifying this scene as the 'Three Youths in a Fiery Furnace'. As described in the book of Daniel, three Hebrew men (Dn 3:1-97) held captive by the Babylonian king Nebuchadnezzar refused to worship the golden statue set up by the king. The angry ruler ordered them to be thrown into a fiery furnace. Despite this, the young men did not burn but walked among the flames praying to God. Nebuchadnezzar's servants did not stop firing the furnace, but the angel of the Lord who descended into the furnace removed the flame so it did not harm the Three Youths. Seeing this miracle, Nebuchadnezzar was surprised, especially since he saw not three men in the oven but four, and the fourth was in appearance similar to an angel. Therefore, Nebuchadnezzar ordered the young men to be released, recognising that it was thanks to the help of the God to whom they had been praying, that they had been saved from the fiery flames. Images of the Three Youths were present in art as of Early Christian times since their story announced the Resurrection and Universal Salvation.

From the earliest images, the youths were shown in orantes positions, standing among flames (however the figure of an angel was introduced gradually); thus, the scene from Faras represents a typical scheme of this composition in which all the figures are standing in one line. ${ }^{43}$ An additional factor allowing for the identification of this scene is its location in the Cathedral's interior. The scene was painted in the narthex, close to the entrance to the Cathedral. This part of the building was reserved for scenes connected with Salvation themes as seen on the example of the two archangels, flanking the western entrance to the Cathedral. Concluding, the text behind the story ${ }^{44}$ and the place in which it is arranged in the building together with the attributes (the angel's wings) and the vestments (the Three Youths' very characteristic 'oriental' garments) compose a set of factors enabling the proper identification of the paintings.

\section{THE INSCRIPTIONS}

An inscription can be a decisive element in identifying a painting if it has been preserved in full. Often, however, the tituli accompanying the images are fragmentarily preserved. This is the example of one of the most beautiful and famous Nubian paintings showing St Anne from Faras (Fig. 11). ${ }^{45}$

Even when it was discovered, the painting was substantially damaged, which can be traced on the basis of photographs taken in situ. Only the upper part of the saint's silhouette has survived, including the head to the shoulders and part of the right hand. The identification

${ }^{43}$ In the mural of the Three Youths from cubiculum 'Velatio', dated to the end of the third century, the role of a messenger of God is played by a bird not by an angel. See: Brenk 1977: 134. The angel seems to have appeared in these scenes only as of the fourth century onwards.

44 Zielińska, Tsakos 2019: 84-85.

45 The mural is currently housed in the National Museum in Warsaw (inv. no. 234058 MNW). 


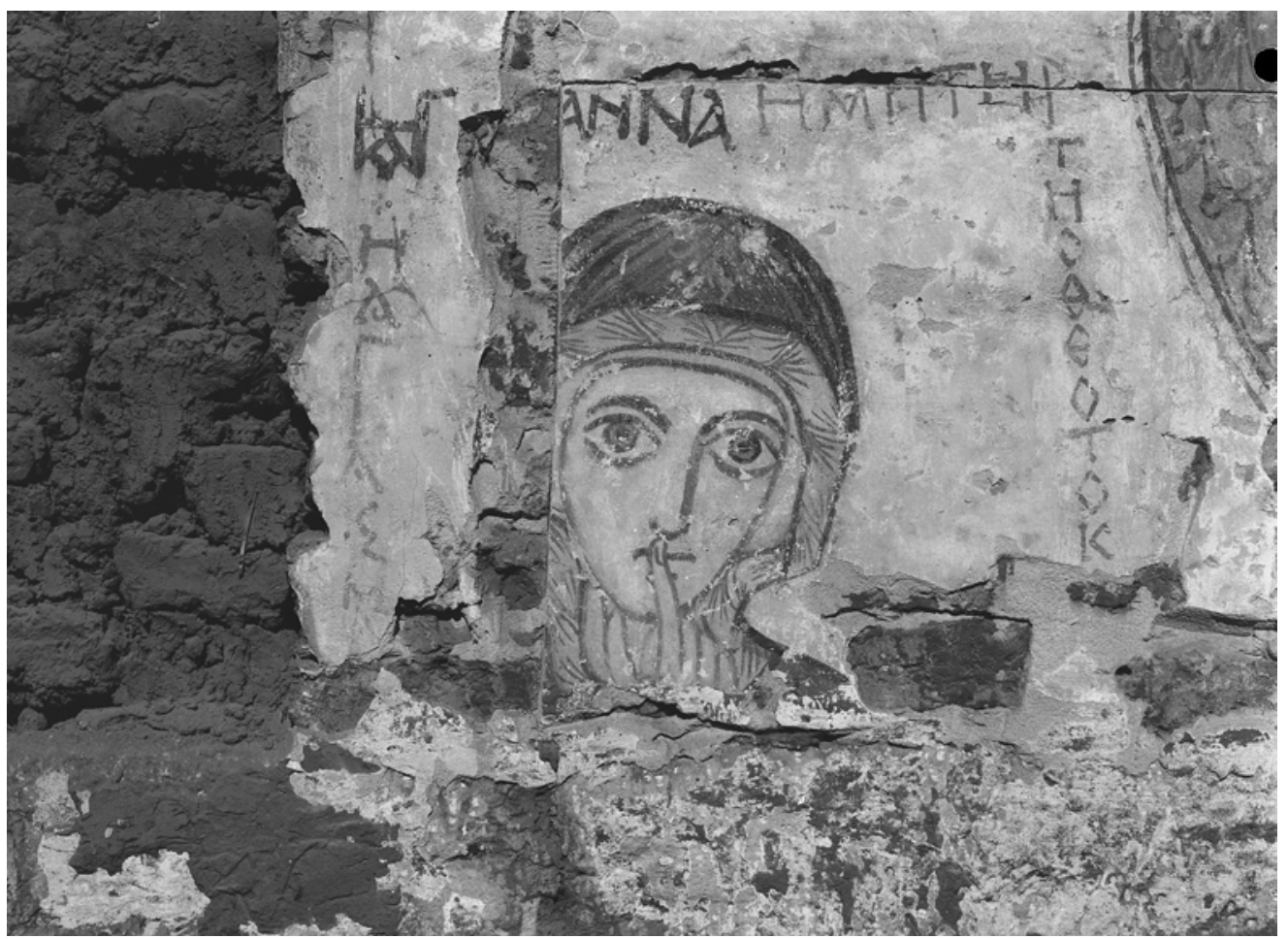

11. St Anne. Faras Cathedral, north aisle, north wall; photo in situ (Phot. A. Dziewanowski; courtesy of IKŚiO PAN).

of the saint could be made on the basis of the titulus in Greek: ANNA H MHTHP TH $\Sigma$ @EOTOKOU, HAGIA KAI MA ... (the rest of the inscription is missing). The scholars focused mainly on analysing Anne's gesture. She is shown placing the forefinger of her left hand up to her lips, in a gesture of silence. Tadeusz Dobrzeniecki devoted a profound study to the iconography of this scene; 46 however, he did not analyse, in detail, the titulus surrounding St Anne’s face. In fact, it was Adam Łukaszewicz, ${ }^{47}$ who did such research, writing an article on the titulus of this image, in which he concentrated on two possible

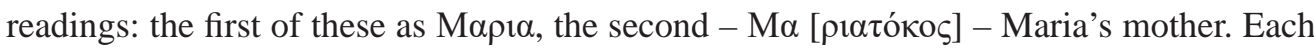
interpretation of this inscription leads to a different identification of the unpreserved fragment of the painting. The first solution - KAI MARIA - may assume that Anna was originally shown on the painting together with Maria. According to the second one, it can be assumed that Anna was portrayed alone. I believe that the first version, assuming that Anna was shown with little Maria, is more likely, because if the lost word was to be

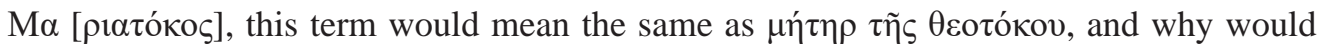
it have been doubled?

\footnotetext{
46 Dobrzeniecki 1988: 95-196.

47 Łukaszewicz 1992: 245-246.
} 
If the inscription describing this painting had not survived at all, no one would probably have realised that the saint represented on the mural was Anna. First of all, she was shown without a halo, secondly - as a young woman, although it is known from apocryphal texts that she was already of a certain age when she became a mother (PJ 1-3,2). Thus, she typically appeared as an elderly woman in $\operatorname{art}^{48}{ }^{4 n}$ this case, the inscription was a decisive element allowing for an interpretation of the image. However, due to its partial preservation and the mural's incompleteness, it had to be carefully analysed. It seems that a similar statement would apply to most of the inscriptions accompanying Nubian painted images.

\section{CONCLUSIONS}

Based on the examples mentioned above, I have tried to show the difficulties in identifying Nubian paintings. These often lead to the impossibility of the proper attribution of the painting.

One can ask whether there is any effective method that would allow for a relatively precise identification of given images? It seems that there are several stages that would allow for a relatively safe procedure. One should begin with providing an exact description of the painting, taking into account the context, and therefore the place in liturgical, residential, or other interiors. The next stage is narrowing down the identification by combining the physiognomic type, the garments and the attributes. One decisive element in this case is the inscription, which allows for a final identification, provided that it is complete. It is important to find the written sources behind the image and - finally - to conduct a comparative analysis, both iconographic and iconological, with emphasis put on the fact that material from Nubia does not always have to be identical to that from Byzantium.

However, one practical problem involves the fact that many interpretations of the paintings are made immediately during the excavations, without the possibility of conducting a deeper analysis. Identifications created in this way are often merged with the images, and are then frequently repeated, making it very difficult to change them and introduce a new perspective on already widely accepted opinions.

\section{Primary Sources}

Origen, De Pricipiis 1885: Origen, On principia, transl. Crombie, F., [in:] Roberts, A., Donaldson, J. (Eds), Fathers of the Third Century: Tertullian, Part Fourth; Phillip Schaff Minucius Felix; Commodian; Origen, Parts First and Second, The AnteNicene Fathers 4, Edinburg 1885, 239-284

Oxford Annotated Bible 2001: The New Oxford Annotated Bible with Apocrypha: New Revised Standard Version, 4th ed., Eds Coogan, M.D., Brettler, M.Z., Newsom, C., Perkins, P., Oxford 2001

Tertullian, Apology 1984: Tertullian, The Apology, transl. Glover, R.T., Cambridge MA 1984

\footnotetext{
${ }^{48}$ Panou 2018: 80, Fig. 3,1.
} 


\section{References}

Allen, P., Mayer, W. 2000: John Chrysostom, Early Church Fathers, New York

Brenk, B. 1977: Spätantike und frühes Christentum, Propyläen Kunstgeschichte, Neue Ausgabe, Supplementum 1, Frankfurt a/Main-Berlin-Wien

Brenk, B. 2010: The Apse the Image and the Icon: An Historical Perspective of the Apse as a Space for Images, Spätantike - Frühes Christentum - Byzanz 26, Wiesbaden

Bryl, M., Juszkiewicz, P., Piotrowski, P., Suchocki, W. (Eds) 2009: Perspektywy współczesnej historii sztuki. Antologia przekładów „Artium Quaestiones”, Poznań

Dobrzeniecki, T. 1988: Święta Anna z Faras w Muzeum Narodowym w Warszawie. Symbolika gestu milczenia, RMNW XXXII, 95-196

Drake Boehm, B. 1984: Icon with full-length figure of St Michael, [in:] Buckton, D. (Ed.), The Treasury of San Marco, Venice, Milan, 171-175

Evans, H.C. (Ed.) 2004: Byzantium: Faith and Power (1261-1557), New York-New Haven-London

Godlewski, W. 1992: Wczesne malowidła ścienne z terenów Nobadii, RMNW XXXVI, 23-38

Innemée, K.C. 1992: Ecclesiastical Dress in the Medieval Near East, Studies in Textile and Costume History 1, Leiden

Iwaszkiewicz-Wronikowska, B. 2003: Głoszenie słowa. Kilka uwag na temat motywu księgi w ikonografii wczesnochrześcijańskiej, Vox Patrum 23/XLIV-XLV, 131-142

Jakobielski, S. 1982: Remarques sur la chronologie des paitures murales de Faras aux VIIIe et IXe siècles, [in:] Jakobielski, S. (Ed.), Nubia Christiana I, Warsaw, 142-172

Jakobielski, S., Martens-Czarnecka, M., Łaptaś, M., Mierzejewska, B., Rostkowska, B. 2017: Pachoras. Faras: The wall paintings from the Cathedrals of Aetios, Paulos and Petros, PAM Monograph Series 4, Warsaw

Jastrzębowska, E. 2011: New Testament Angels in Early Christian Art: Origin and Sources, Światowit VIII/XLIX, fasc. A (2009-2010), 153-164

Krauze, A. 2012: Od antycznej bogini do chrześcijańskich aniołów, czyli o przekraczaniu granic ikonograficznych, [in:] Banasiak, S., Gumiela, P., Kłos, J., Szada, M. (Eds), Centrum - Peryferia - Granice, Materiały z VI Studenckiej Konferencji Starożytniczej, Kraków 6-8 maja 2010, Warszawa, 27-48

Łaptaś, M. 1996: Paintings from the Faras Cathedral. The „Colour” Classification Method, Nubian NoteLet 2, 1-18

Łaptaś, M. 2015: Symbolika oczu na skrzydłach archaniołów w malarstwie nubijskim, [in:] Olszewska, M., Skrodzka, A. (Eds), Initium Sapientiae Humilitas. Studia ofiarowane Profesorowi Jakubowi Pokorze z okazji 70. urodzin, Warszawa, 42-55

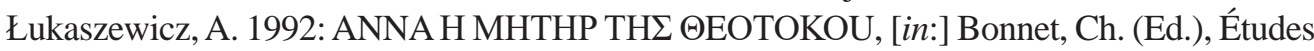
nubiennes. Conférence de Genève. Actes du VII ${ }^{\text {e }}$ Congrès international d'études nubiennes, 3-8 septembre 1990, II: Communications, Geneva, 245-246

Mango, C., Hawkins, E.J.W. 1972: The Mosaics of St. Sophia at Istanbul. The Church Fathers in the North Tympanum, DOP 26/1, 3-41 
Martens-Czarnecka, M. 1974: Księga jako motyw ikonograficzny w malarstwie ściennym w katedrze w Faras, RMNW XVIII, 309-335

Martens-Czarnecka, M. 2001: Wall Paintings Discovered in Old Dongola, [in:] Jakobielski, S., Scholz, P.O. (Eds), Dongola-Studien. 35 Jahre polnischer Forschungen im Zentrum des makuritischen Reiches, Bibliotheca nubica et aethiopica 7, Warsaw, 253-284 Martens-Czarnecka, M. 2011: The Wall Paintings from the from the Monastery on Kom H in Dongola, PAM Monograph Series 3, Nubia III, Dongola 3, Warsaw

Martin, Th. 2001: The Development of Winged Angels in Early Christian Art, [in:] Espacio, Tiempo y Forma, Serie VII, Historia del Arte 14, 11-29

McCormick, M. 1991: Porphyrogenetos, [in:] ODB 3, 1701

Michałowski, K. with contribution by Jakobielski, S. 1974: Faras: Wall Paintings in the Collection of the National Museum at Warsaw, Warsaw

Mierzejewska, B. 2014: The Professor Michałowski Faras Gallery. A Guide. National Museum in Warsaw, Warsaw

Müller, C.D.G. 1959: Die Engellehre der Koptische Kirche: Untersuchungen zur Geschichte der christlichen Frömmigkeit in Aegypten, Wiesbaden

Ostrowski, J.A. 2003: Nike i Wiktoria - ikonograficzne pierwowzory aniołów, [in:] Oleschko, H. (Ed.), Księga o aniołach, Kraków, 473-483

Pallas, D.I. 1972: Himmelsmächte, Erzengel und Engel, [in:] RBK III, 13-120

Panofsky, E. 1939: Studies in Iconology: Humanistic Themes in the Art of the Renaissance, New York-Oxford

Panou, E. 2018: The Cult of St Anna in Byzantium, Birmingham Byzantine and Ottoman Studies 24, London-New York

Patterson Ševcenko, N. 1991: Omophorion, [in:] ODB 3, 1526

Peers, G. 2001: Subtle Bodies. Representing Angels in Byzantium, Transformation of the Classical Heritage 32, Berkeley-Los Angeles-London

Petzold, A. 2017: The Iconography of Color, [in:] Hourihane, C. (Ed.), The Routledge Companion to Medieval Iconography, New York, 441-456

Poeschke, J. 2009: Mosaiken in Italien 300-1300, München

Rostovtzeff, M.I. (Ed.) 1934: The Excavations at Dura-Europos conducted by Yale University and the French Academy of Inscriptions and Letters: Preliminary Report of the fifth season of work, October 1931-March 1932, New-Heaven-London-Prague

Weitzmann, K. 1948: The Joshua Roll: A Work of the Macedonian Renaissance, Studies in Manuscript Illumination 3, Princeton

Woźniak, M.M. 2014: Royal Iconography: Contribution to the Study of Costume, [in:] Anderson, J.R., Welsby, D.A. (Eds), The Fourth Cataract and Beyond. Proceedings of the 12th International Conference for Nubian Studies, Leuven-Paris-Walpole MA, 929-942

Zielińska, D., Tsakos, A. 2019: Following the footsteps of an archangel. The representations of the Archangel Michael in the framework of the project 'Corpus of wall paintings from Medieval Nubia’, [in:] Gilhus, I.S., Tsakos, A., Wright, M.C. (Eds), The Archangel Michael in Africa: History, Cult, and Persona, London, 79-94 


\section{ÉTUDES et TRAVAUX XXXII / 2019}

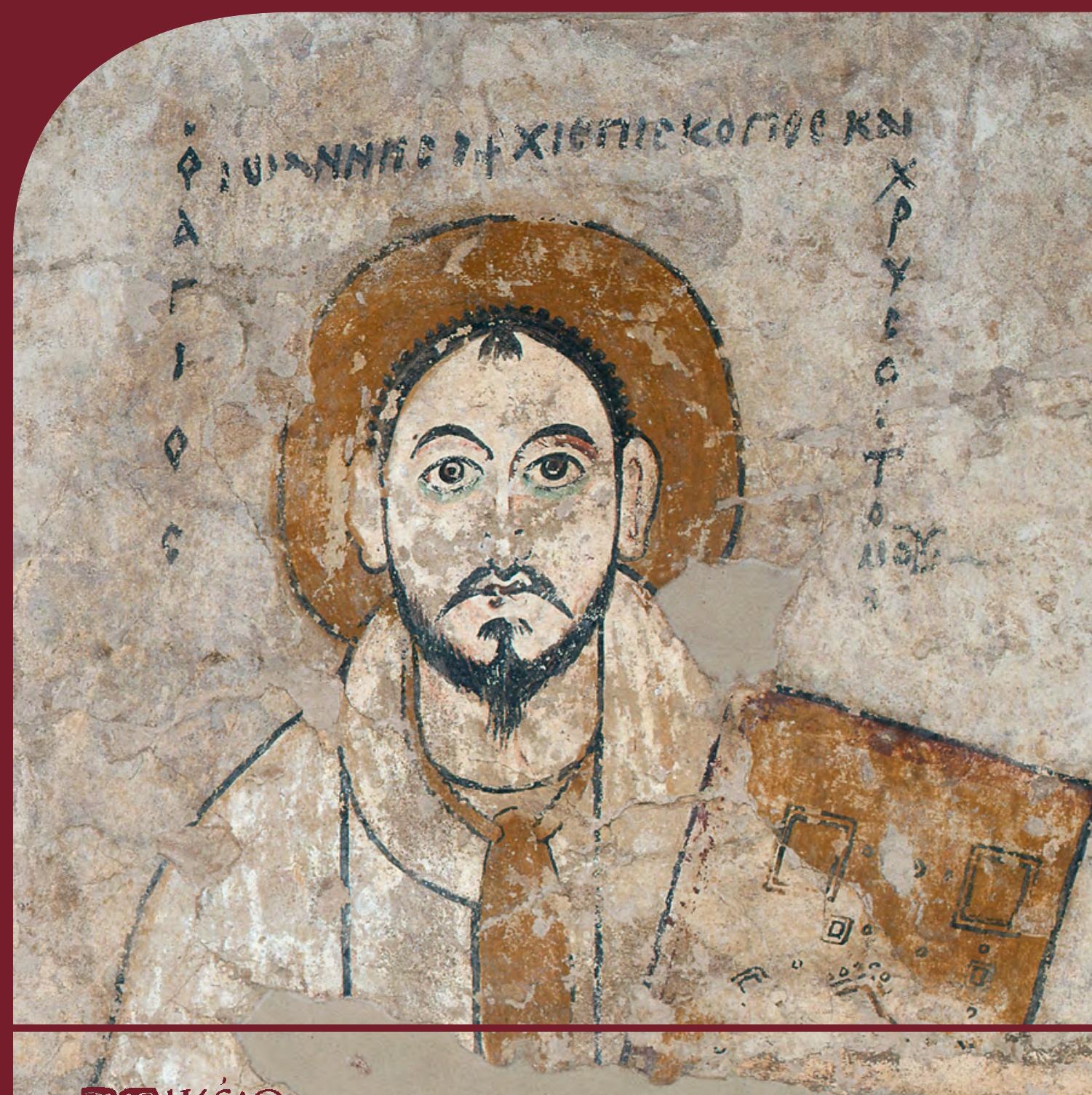

BOMIKSiO Institut des Cultures Méditerranéennes et Orientales ED2A PAN de l'Acácémie Polonaise des Sciences 


\title{
COMITÉ DE RÉDACTION SCIENTIFIQUE
}

Maciej Makowski - rédacteur en chef Jadwiga Iwaszczuk - rédacteur

Maciej G. Witkowski - rédacteur

Agnieszka Ryś - sécretaire de la rédaction

Bogdan Żurawski - rédacteur thématique du volume

CONSEIL SCIENTIFIQUE DU JOURNAL

M. Kobusiewicz (IAE PAN, Warszawa), E. Laskowska-Kusztal (IMOC PAS, Warszawa),

D. Michaelides (University of Cyprus, Nicosia),

J.Ch. Moretti (IRAA-MOM, Université de Lyon 2/CNRS),

D. Raue (Ägyptisches Museum der Universität Leipzig), P. Reynolds (ICREA, España),

D. Welsby (British Museum, London)

\section{COMITÉ SCIENTIFIQUE DE LECTURE}

D.E. Arnold (Wheaton College/The Field Museum, Chicago), H.D. Baker (University of Toronto),

P. Ballet (ArScAn-ESPRI, Université Paris Nanterre), Ch. Barber (Princeton University),

N. Beaux-Grimal (IFAO, Caire/Collège de France, Paris), A. Boud'hors (CNRS, IRHT, Paris),

J. Budka (Ludwig-Maximilians-Universität München), R. David (SFDAS),

A. Delattre (CPEG, Bruxelles), A. Dodson (University of Bristol),

E. Fogliadini (Facoltà Teologica dell'Italia Settentrionale, Milan),

V. Francigny (CNRS/CRES, Paris), L. Gabolde (CNRS), C. Gobeil (Egypt Exploration Society, London),

N. Hamdi (UCL, Louvain), J. den Heijer (CIOL/INCAL, Louvain-la-Neuve),

S. Ikram (American University in Cairo), Ch. Leitz (Universität Tübingen), S. Ortisi (Universität München),

E. Rova (Università Ca' Foscari Venezia), G. Ruffini (Fairfield University),

A. Sasson (San Diego Natural History Museum), H. Satzinger (Universität Wien),

S.M. Schellinger (The Ohio State University, Columbus), G. Schreiber (Eötvös Loránd University, Budapest),

E. Teeter (University of Chicago), S. Torallas-Tovar (University of Chicago),

Y. Tristant (Macquarie University, Sydney), V. Vaelske (independent researcher),

H. Vymazalová (Charles University, Prague), P. Weschenfelder (Universität Wien),

B. Williams (University of Chicago/PCMA UW, Warszawa),

K. Winther-Jacobsen (The Danish Institute at Athens), E. Zacharopoulou (University of Johannesburg),

P. Grotowski (UPJPII, Kraków), E. Papuci-Władyka, J. Śliwa (IA JU, Kraków), A. Ćwiek (IA AMU, Poznań),

K.O. Kuraszkiewicz, M. Pinker (FOS UW, Warszawa), Ł. Niesiołowski-Spanò (IH UW, Warszawa),

M. Gawlikowski, Mahmoud El-Tayeb (PCMA UW, Warszawa), S. Rzepka (IA UW, Warszawa)

\author{
RÉDACTION TECHNIQUE \\ Monika Wesołowska
}

REVUE DES TEXTES ANGLAIS

Jo Harper 
ÉTUDES et TRAVAUX

XXXII 
INSTYTUT KULTUR ŚRÓDZIEMNOMORSKICH I ORIENTALNYCH POLSKIEJ AKADEMII NAUK

\title{
STUDIA i PRACE
}

\author{
XXXII
}

gू IKŚiO

ESAN

WARSZAWA

2019 
INSTITUT DES CULTURES MÉDITERRANÉENNES ET ORIENTALES DE L’ACADÉMIE POLONAISE DES SCIENCES

\section{ÉTUDES et TRAVAUX}

XXXII

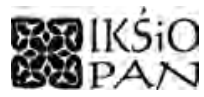

VARSOVIE

2019 
Publication scientifique financée dans le cadre du programme du Ministre de la Science et de l’Éducation Supérieure

« Programme National de Développement de l’Humanistique » pour les années 2016-2021 (projet no $3 b H 150099$ 83)

\title{
TI NARODOWY PROGRAM ROZWOJU HUMANISTYKI
}

\author{
Copyright $(\mathbb{C}$ \\ Instytut Kultur Śródziemnomorskich i Orientalnych PAN \\ et les Auteurs \\ Warszawa 2019
}

\begin{abstract}
ISSN 2084-6762
(avant 2011 : 0079-3566)

e-ISSN 2449-9579

Version première en papier, imprimée en Pologne - 150 copies

Version électronique accessible sur

http://www.etudesettravaux.iksiopan.pl
\end{abstract}

Édition: Polskie Towarzystwo Historyczne et Wydawnictwo Neriton, Warszawa

Conception générale de couverture : J. Iwaszczuk

Photo de couverture : P. Ligier ; courtoisie du Musée National de Varsovie

(Saint Jean Chrysostome, peinture, cathédrale de Faras). 


\section{Table des matières}

Editorial: Quid novi ex Nubia (par Bogdan Żurawski) ............................................... 7

Bibliography of Professor Stefan Jakobielski ................................................................ 13

Aneta Cedro, Bogdan Żurawski

Living with the Past in Modern Sudanese Village. Traditional Pottery Production

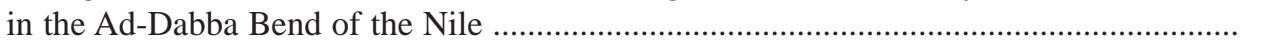

DAVID N. EDWARDS

A Possible Monastery and the 'Upper Maqs’ at Ukma-Akasha West? ............................ 53

Vincent W.J. van GeRven OeI

An Old Nubian Curse from the Faras Cathedral ........................................................ 81

Vincent W.J. van Gerven Oei, Adam Łajtar

Two Old Nubian Inscriptions from Akasha West ........................................................ 89

Vincent W.J. van Gerven Oei, Alexandros Tsakos

Rubrication Patterns in Two Old Nubian Manuscripts from Serra East .......................... 99

KAREL C. INNEMÉE

A Man in a Vessel, Once More .................................................................................. 111

KAREL C. INNEMÉE, Dobrochna ZielińSKA

Faces of Evil in Nubian Wall-Painting - An Overview ................................................ 121

ADAM ŁAJTAR

Epitaph of Merki Found in Hambukol ....................................................................... 145

MAGDALENA ŁAPTAŚ

Attributes, Vestments, Context and Inscription in the Identification of Nubian

Paintings: Proposing the 'Multi-Layer' Image Recognition Method ............................... 161

Grzegorz Ochala

Nubica Onomastica Miscellanea I: Notes on and Corrections to Personal Names

Found in Inscriptions from Faras 


\section{Robin SEIGNOBOS}

L'influence du Kitāb ahbār al-Nūba d'Ibn Sulaym al-Uswānī sur l'Histoire des églises et monastères d'Égypte d'Abū al-Makārim

JACQUES VAN DER VLIET

Exit Bishop Tamer - the Sequel. A New Edition of the Epitaph of Papsine alias Doulista (DBMNT 78) 